\title{
Non-invasive monitoring of changes in rabbit hearts with aging using MR microscocpy
}

\author{
Min-Sig Hwang ${ }^{1 *}$, Katja E Odening ${ }^{2}$, Bum-Rak Choi ${ }^{2}$, Gideon Koren², Stephen J Blackband ${ }^{1}$, John R Forder ${ }^{1}$ \\ From 2011 SCMR/Euro CMR Joint Scientific Sessions \\ Nice, France. 3-6 February 2011
}

\begin{abstract}
Background
Loss of myocytes followed by compensatory hypertrophy of the remaining cells and interstitial fibrosis are common hallmarks observed in aging hearts $[1,2]$. The cardiac conduction system is also subject to alterations with aging, resulting in reduced thresholds to diseases [3]. Biopsy is an accurate and informative means to delineate the age-related changes. However, it is destructive and requires intensive labor, often with severe complications for 3D reconstruction. The aim of this study was to investigate non-invasively morphological changes in aging heart using MR microscopy.
\end{abstract}

\section{Materials and method}

Isolated heart preparation

Hearts $(\mathrm{n}=5)$ of New Zealand White male rabbits (2-5 kg) were isolated and fixed in situ according to the approved animal protocol. Young hearts $(\mathrm{n}=2)$ were 6 month $\sim 1$ year old. Old hearts were $3 \sim 4$ years old.

\section{MRI}

MR experiments were performed on a $17.6 \mathrm{~T} / 89 \mathrm{~mm}$ vertical wide-bore magnet (Bruker Instruments, Billerica, MA). Three dimensional MR microscopy data were collected using a fast gradient pulse sequence, achieving a voxel resolution of $35 \times 35 \times 82 \mu \mathrm{m}^{3}$. High angular resolution diffusion microscopy (HARDM) using 21 directions was performed with a standard PGSE sequence, achieving an in-plane resolution of $60 \mu \mathrm{m}^{2}$ with a slice thickness of $600 \mu \mathrm{m}$. The b-value was $1000 \mathrm{~s} / \mathrm{mm}^{2}$.

\section{Data analysis}

Volume rendering of the 3D MR data sets was performed using ImageJ (ver. 1.31, http://rsbweb.nih.gov/ij/). The

${ }^{1}$ McKnight Brain Institute, University of Florida, Gainesville, FL, USA

Full list of author information is available at the end of the article tensor processing of HARDM data sets was conducted using fanDTasia ${ }^{\mathrm{m}}$ (@2008, http://www.cise.ufl.edu/ abarmpou/) and MATLAB (Mathsoft, Cambridge, MA).

\section{Results}

Aging in the rabbit heart results in significantly increased interseptal thickness (Fig.1). Volume rendered transverse images of the apical half suggest that the free-running Purkinje fiber network in the LV cavity may significantly alter with aging (Fig. 1). Dense reticular net observed in young ventricles becomes sparse with aging and the free running Purkinje fibers become thinner. From HARDM, aging in rabbit heart appears to be associated with increased radial diffusivity, which may arise from cellular hypertrophy (data not shown). A tensor component map of a young heart $\left(D_{y z}\right)$ shows a well defined stripe pattern extending transmurally in the interseptum and left ventricular freewall (Fig. 2, left). In contrast, this highly directional structure was decreased in aged hearts (Fig.2, right). A volume rendered image of interseptum shows that

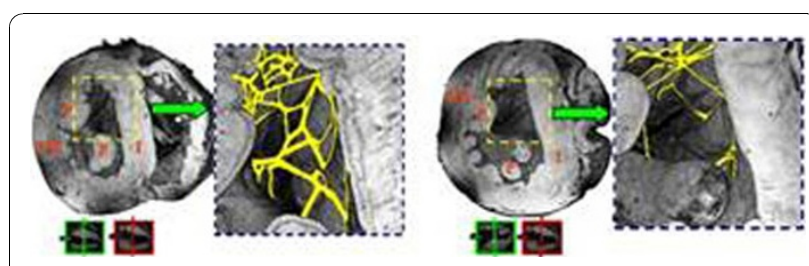

Figure 1 Volume rendered transverse images and manual separation (magnified) of the free-running Purkinje fiber network in the LV of a young rabbit heart (left) and an old rabbit heart (right). Lines and arrows in the green and red boxes indicate where sectioning occurred and viewer was located. Interseptal thickness is approximately $3.93 \mathrm{~mm}$ (young) and $4.82 \mathrm{~mm}$ (old). I: ventricular interseptum, P: papillary muscle, FW: free wall.

\section{C) Biomed Central}

(C) 2011 Hwang et al; licensee BioMed Central Ltd. This is an open access article distributed under the terms of the Creative Commons Attribution License (http://creativecommons.org/licenses/by/2.0), which permits unrestricted use, distribution, and reproduction in any medium, provided the original work is properly cited. 


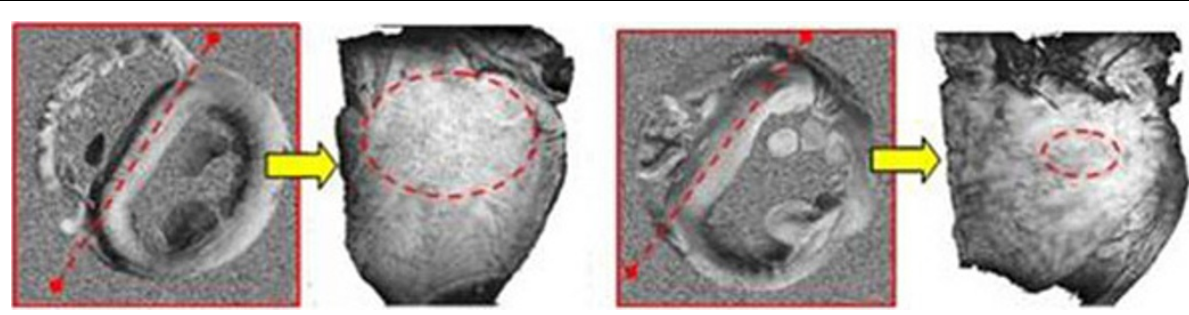

Figure 2 Tensor component $\left(D_{v s}\right)$ map from HARDI and a volume rendered image of the interseptum of a young rabbit heart (left) and an old rabbit heart (right). Dotted lines (red) indicate where sectioning occurred and dotted circles confine regions where the stripe pattern in observed.

the stripe pattern has a longitudinal direction and appears to exist in the basal half of the LV.

\section{Acknowledgement}

Magnetic resonance microscopy was performed using $17.6 \mathrm{~T}$ magnet at Advanced Magnetic Resonance Imaging and Spectroscopy center and the McKnight Brain Institute. Funding for this work was provided by the $\mathrm{NIH}$ (1R01EB012874), the NSF through the National High Magnetic Field Laboratory, and seed grants (JRF) from the McKnight Brain Institute and the Department of Radiology, UF.

\section{Author details}

${ }^{1}$ McKnight Brain Institute, University of Florida, Gainesville, FL, USA.

${ }^{2}$ Cardiovascular Research Center, The Rhode Island Hospital, Alpert Medical

School of Brown University, Providence, RI, USA.

Published: 2 February 2011

\section{References}

1. Olivetti G, et al: Circ Res 1991, 68:1560-1568.

2. Brooks A, et al: Heart 2003, 89:1255-1256.

3. Pugh K, Wei J: Drugs and Aging 2001, 18:263-276.

\section{doi:10.1186/1532-429X-13-S1-P361}

Cite this article as: Hwang et al:: Non-invasive monitoring of changes in rabbit hearts with aging using MR microscocpy. Journal of Cardiovascular Magnetic Resonance 2011 13(Suppl 1):P361.

\section{Submit your next manuscript to BioMed Central} and take full advantage of:

- Convenient online submission

- Thorough peer review

- No space constraints or color figure charges

- Immediate publication on acceptance

- Inclusion in PubMed, CAS, Scopus and Google Scholar

- Research which is freely available for redistribution

Submit your manuscript at www.biomedcentral.com/submit 